\title{
比例摩擦ダンパを用いた受動形振動絶縁・抑制システム*
}

\author{
佐 藤 義 仁*1, 山口 秀 谷*2, 大久保 宏樹*2
}

\section{Passive Vibration Isolation-Reduction System by Linear Friction Damper}

\author{
Yoshihito SATOH, Hideya YAMAGUCHI ${ }^{* 3}$ and Hiroki OKUBO \\ ${ }^{* 3}$ Department of Mechanical Systems Engineering, National Defense Academy, \\ 1-10-20 Hashirimizu, Yokosuka-shi, Kanagawa, 239-8686 Japan
}

\begin{abstract}
For the passive vibration isolation system, a friction damper is often used becasue it is sipmle, inexpensive and robust. However, the conventional damper of constant friction force has performance limitations; the isolation characteristic declines when the friction force is large, while the resonant peak becomes large when the friction force is small. Furthermore, the displacement remains apart from the equilibrium position after the vibration diminishs. In order to overcome above drawbacks of the conventional friction damper, a new type of friction damper is proposed in this paper. In the new friction damper, the friction lever mechanism is devised to make the magnitude of the friction force proportional to the relative displacement. This is achieved by connecting the end of the lever to the restoring spring. The transient response and the displacement transmissibility are examined by numerical simulation and experiments, confirming the effectiveness of the linear friction damper.
\end{abstract}

Key Words: Vibration Isolation, Vibration Reduction, Friction Damper, Linear Friction, Transmissibility, Coulomb friction, Forced Vibration, Free Vibration, Stick-slip

\section{1. 緒}

振動絶緑装置あるいは免震装置は, 種々の方式が提 案されている．近年はアクチュエー夕を用いた能動形 の研究が盛んに行われており, 高度な振動制御が実用 化されつつあるが(1), 設備経費や保守管理の面で難点 がある、ばねとダンパで構成された受動形を改善する 研究も各種行われている。粘性減衰形ダンパを用いた 受動形振動絶縁方式では, 共振ピークを低減するため には減衰比を大きくする必要があるが, 減衰比を大き くすると高振動数の絶緑領域の伝達率が大きくなって 絶縁性が悪化するため, 性能の限界がある.

一方, 滑り摩擦(固体摩擦)を利用した摩擦ダンパは 簡便な構造で, 機器類や建物などの大形構造物にも用 いられているが(2) (4), 腐食や経年変化による摩擦係数 の変化の問題や残留変位の問題がある.この種の研究 として, 予引張ばねを利用した免震床の研究(5), 摩擦 ダンパを片効き化して残留変位を抑制する研究(6)な どがなされている．また，摩擦力一定のダンパでは，

* 原稿受付 2004 年 3 月 23 日.

*1 防衛大学校理工学研究科前期課程 (239-8686 横須賀市走 水 1-10-20).

*2 正員, 防衙大学校 (-2398686 横須賀市走水 1-10-20).

E-mail : hideya@nda.ac.jp
摩擦力が小さい場合は共振ピークが無限大となり，摩 擦力が大きくなると共振ピークはなくなるが, 振動絶 緑されない振動数域が広がることが知られてい $ろ^{(7)(8)}$.

ところで, Beucke ら (9) は,クーロン摩擦力が実際 には一定ではなく振幅に比例して増加するという実験 結果をもとに, 摩擦力が変位に比例して変化するモデ ルを用いて 1 自由度振動系の応答を調べている。 た, Makris ら ${ }^{(10)(11)} も$ 同様のモデルで, 特にスティッ ク・スリップ問題に重点をおいて, 変位に比例して変 化する摩擦力の影響を調べている。なお，これらの研 究は, テフロンのような材料の摩擦特性が振動振幅に 比例して変化することに応じて研究を行っており, 摩 擦力が変位に比例して変化する特別な機構を設けてい るものではない. 一方, Tadjbakhsh ら ${ }^{(12)}$ は免震建物 において, 摩擦板を複数枚組合わせて, 相対変位が生 じると外側の摩擦板に取付けたケーブルが引張られ， 摩擦板間の押付け力が増加する装置を提案している.

本研究では，振動絶縁性能を低下させることなく共 振ピークを抑制し，また残留変位を最小化するために， 相対変位に比例して摩擦力の大きさを変化させる新た な機構(比例摩擦ダンパ)を提案し，その特性を数值シ ミュレーションおよび実験によって調べる. 


\section{2. 振動絶縁装置の機構}

本研究で提案する振動絶縁装置の作動原理モデルを 図1 亿示す。図1 亿おいて, 振動絶縁対象物を搭載す るテーブルはリニアガイドで支持され，さらに，テー ブルに取付けた支点まわりに回転可能な二組のレバー とばね系を介して基礎に連接されている。なお，これ らのレバーとばねの系は互いに逆向きに組付けられて いる. テーブルと基礎との間に相対変位が生じると, ばねはテーブルに復原力を与えるとともにレバーにモ ーメントを発生させる.テーブル, 基礎の絶対変位を それぞれ $x, x_{0}$ とし, 相対変位を

$$
z=x-x_{0}
$$

とすると, $z>0$ の場合にはレバー A の先端は摩擦板 に押付けられて摩擦力を発生し, レバーB の先端は摩 擦板から離れるが，わずかだけ離れたらストッパ B で 拘束される.

図 2 は $z>0, \dot{z}>0$ の場合のレバーA に作用する力 の詳細を示し, $P_{A}$ はば龵 $\mathrm{A}$ による復原力, $N$ および $F_{d}$ : は摩擦板との間作用する垂直力および摩擦力で ある. 支点 $\mathrm{A}$ から力 $P_{A}, N, F_{d}$ の作用線までの距離

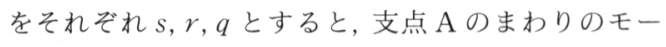
メントの釣合いより

$$
s P_{A}+q F_{d}-r N=0
$$

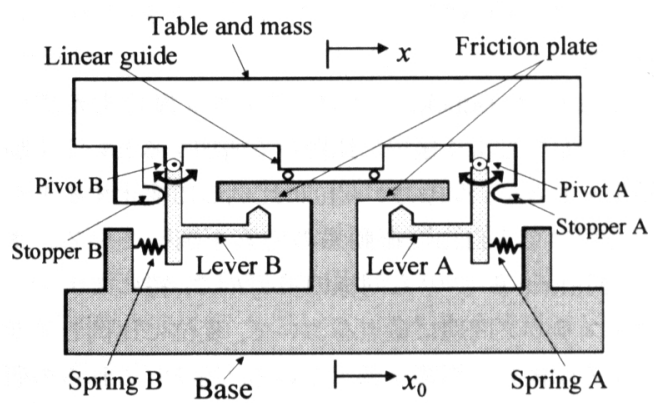

Fig. 1 Scheme of linear friction damper vibration isolation system

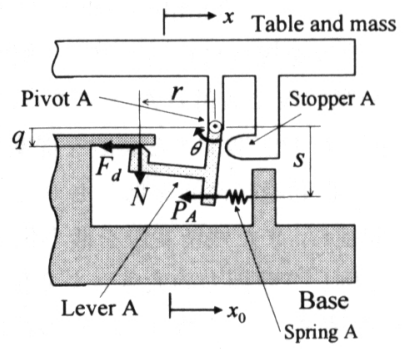

Fig. 2 Forces acting on lever $\mathrm{A}(z>0, \dot{z}>0)$
となる。摩擦力としてクーロン摩擦を仮定し, 摩擦係 数を $\mu$ とすると

$$
F_{d}=\operatorname{sign}(\dot{z}) \mu N
$$

であるので，式（2），(3) より $N$ を消去すると

$$
F_{d}=\operatorname{sign}(\dot{z}) \frac{\mu \varepsilon}{1-\operatorname{sign}(\dot{z}) \mu \beta} P_{A} \ldots
$$

を得る。ここに

$$
\varepsilon=s / r, \quad \beta=q / r
$$

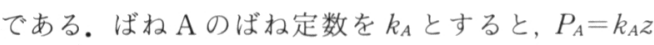
であるので, $F_{d} も z$ に比例することになる. 以後, $F_{d}$ を比例摩擦力と呼び, 通常の大きさ一定の摩擦力 と区別する。一方，レバーB はストッパ Bで拘束さ れているため, ば权定数 $k_{B}$ のば齐によって作用する

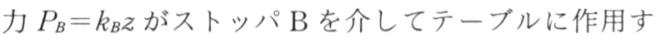
る.なお，レバーとストッパのすきまは微小に設定し てあり、レバーの回転角 $\theta$ はほぼ零とみなす。さら に，リニアガイド等によって作用する一定摩擦力を

$$
F_{c}=\operatorname{sign}(\dot{z}) F_{c 0}
$$

とする。テーブルに作用する合力 $F$ は, 以上の比例 摩擦力 $F_{d}$, ば权力 $P_{A}, P_{B}$ 抢上び一定摩擦力 $F_{C}$ の和 となり, 次式で表される.

$$
\begin{aligned}
F & =F_{d}+P_{A}+P_{B}+F_{c} \\
& = \begin{cases}k_{p} z+F_{c 0} & (\dot{z}>0) \\
k_{m} z-F_{c 0} & (\dot{z}<0)\end{cases}
\end{aligned}
$$

ここに

$$
k_{D}=k+\frac{\mu \varepsilon}{1-\mu \beta} k_{A}, k_{m}=k-\frac{\mu \varepsilon}{1+\mu \beta} k_{A}
$$

であり, $k=k_{A}+k_{B}$ である.式(7) は, 見掛け上比例 摩擦力がば权の復原力と同様に作用することを示す。 以降, $k_{p}, k_{m}$ を等価ば社定数と呼ぶ. 合力 $F$ と相対 変位 $z$ の関係を図示すると図 $3(\mathrm{a})$ の上うになる。な お, 図中の矢印はテーブルの運動方向を表す。また, 図3(b) はレパーが摩擦板を押付けないように固定し て, 比例摩擦力 $F_{d}=0$ とした場合の復原力の変化であ る.

テーブルが振動している場合, 系の力学的エネルギ 一は摩擦力によって消散する. $z$ が調和振動して 1 周

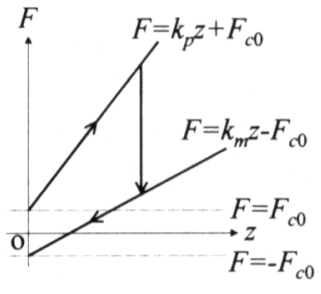

(a) $\quad F_{d} \neq 0$

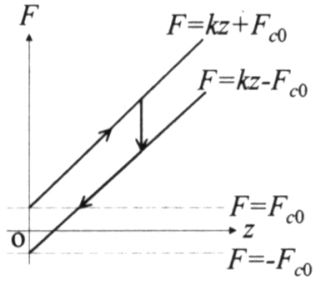

(b) $\quad F_{d}=0$
Fig. 3 Restoring force diagram 
期変動する間に消散されるエネルギー $U_{D}$ は

$$
\begin{aligned}
U_{D} & =2 \int_{0}^{z \max }\left(k_{p} z+F_{c 0}\right) d z+2 \int_{z \max }^{0}\left(k_{m} z-F_{c 0}\right) d z \\
& =\left(k_{p}-k_{m}\right) z_{\max }^{2}+4 F_{c 0} z_{\max } \cdots \cdots \cdots \cdots \cdots \cdots \cdots \cdots \cdots \cdots \cdots \cdots \cdots(9)
\end{aligned}
$$

である.ここに $z_{\max }$ は $z$ の振幅である. 式 $(9)$ 第 1 項め $U_{D P}=\left(k_{p}-k_{m}\right) z_{\max }^{2}$ は比例摩擦力によるエネル ギー消散, 第 2 項め $U_{D C}=4 F_{C 0} z_{\max }$ は一定摩擦力によ るエネルギー消散である. 比例摩擦力のエネルギー消 散 $U_{D P}$ は粘性減衰と同様に $z_{\max }$ の二乗に比例し, $k_{p}$ $>k_{m}$ で $k_{p}$ と $k_{m}$ の差が大きいほど大きくなることが わかる.ところで, 式( 8 )より

$$
k_{p}-k_{m}=\frac{2 \mu \varepsilon}{1-(\mu \beta)^{2}} k_{A}
$$

であるので, エネルギーが消散するためには, $\varepsilon>0$ の 場合

$$
1-(\mu \beta)^{2}>0
$$

となる必要があり, また, $(\mu \beta)^{2}$ が 1 に近いほど消散 量は大きくなることが予測される.さらに, 式(11)の 条件では, $\beta$ は必ずしも正である必要はない. $\beta$ が正 であるのは図 4(a)のように比例摩擦力 $F_{d}$ とばね力 $P_{A}$ の作用線が支点 $\mathrm{A} に$ 関して同じ側にある場合であ り, 図 4(b)のようにこれらの作用線が支点 A に関し て逆側になる場合には $\beta<0$ となる.

\section{3. 運動方程式およびシミュレーション}

\section{振動絶縁装置のテーブルの運動方程式は}

$$
m \ddot{x}=-F+Q
$$

ここに, $m$ は振動絶縁対象物とテーブルの合計質量, $Q$ はテーブルに直接作用する外力である.さらに, 装 置の左右の仕様が対称と仮定し, 式 ( 7 )を考慮して式 (12)を整理すると, テーブルの運動方程式は

$$
\ddot{z}+\omega_{0}^{2}(1+\eta) z=-\ddot{x}_{0}+\alpha-\omega_{0}^{2} d \cdot \cdots
$$

となる.ここに
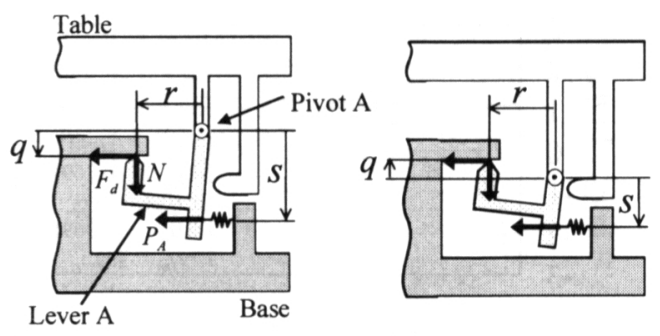

(a) $\beta=q / r>0$

(b) $\beta=q / r<0$

Fig. 4 Lever specification

$$
\left.\begin{array}{l}
\omega_{0}^{2}=\frac{k}{m}, \quad \alpha=\frac{Q}{m}, \quad d=\operatorname{sign}(\dot{z}) d_{0} \\
\eta=\operatorname{sign}(z \dot{z}) \frac{\mu \varepsilon}{2(1-\operatorname{sign}(z \dot{z}) \mu \beta)}
\end{array}\right\}
$$

であり, $k_{A}=k_{B}=k / 2$ と仮定している.また， $d_{0}=$ $F_{c 0} / k$ 泘擦変位である。

数值シミュレーションによって制振性能および振動 伝達率を調べるため, 時刻歴応答を求める必要があ る.シミュレーションは, 式(13)を状態式で表し,一 定時間間隔で離散化して繰返し計算を行う。なお, 相 対速度 $\dot{z}$ の符号が変化する区間では, $\dot{z}=0$ となる瞬 間を二分法により探索し，4章に示す手順で摩擦板と レバー間の滑り, 固着などの判定を行っている.

\section{4. 滑りと固着状態の切換判定}

式(13)を書き改めて

$$
\ddot{z}=\omega_{0}^{2}\left(F_{T}-F_{R}\right)
$$

とする.ここに

$$
\left.\begin{array}{l}
F_{T}=-z-\left(\ddot{x}_{0}-\alpha\right) / \omega_{0}^{2} \\
F_{R}=\eta z+d
\end{array}\right\}
$$

であり, $F_{T}$ はばね復原力, 基礎部からの加振力およ び外力の合力, $F_{R}$ は一定摩擦力および比例摩擦力の 合力に対応するパラメータである. $\alpha=0$ の場合の $F_{T}$ と $F_{R}$ の関係を図示すると図 5 のようになる. 図 5 に おいて, $\eta_{p}, \eta_{m}$ はそれぞれ $z \dot{z}$ の符号の正負に対応す る $\eta$ を表し, $F_{R}^{P M}$ の右上添字 $P M$ 等は $z$ おび $z \dot{z}$ の符号の正 $(\mathrm{P})$, 負 $(\mathrm{M})$ に対応する $F_{R}$ を表す.

$\dot{z}=0$ の状態で, $z$ が

$$
F_{T}>F_{R}^{M M} \text { あるいは } F_{T}>F_{R}^{P P}
$$

の範囲にあれば, 以降は $\dot{z}>0$ の滑り状態となる。一 方, $z$ が

$$
F_{T}<F_{R}^{M P} \text { あるいは } F_{T}<F_{R}^{P M} \cdots
$$

の範囲にあれば, 以降は $\dot{z}<0$ の滑り状態となる.ま た,これらの条件が成立しない場合は $\dot{z}=0$ の固着状 態が継続し, 摩擦力 $F_{R}$ は $F_{T}$ に等しくなる.これら

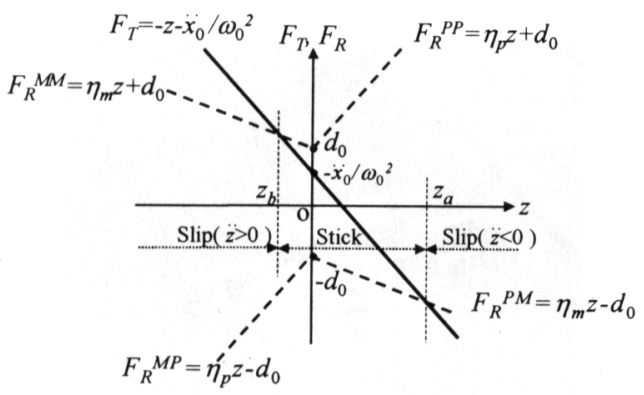

Fig. 5 Relationship between $F_{T}$ and $F_{R}$, and slip-stick condition $(\alpha=0)$ 
の関係は時々刻々変化するが, 基礎部が

$x_{0}=X_{0} \sin \omega t$

で正弦波変位加振された場合には

$|z|>\left(d_{0}+\omega^{2} X_{0} / \omega_{0}^{2}\right) /\left(1+\eta_{m}\right)$

の範囲で常に滑り状態となり,さらに, $d_{0}>\omega^{2} X_{0} / \omega_{0}^{2}$ の場合には

$$
|z|<\left(d_{0}-\omega^{2} X_{0} / \omega_{0}^{2}\right) /\left(1+\eta_{m}\right)
$$

の範囲で常に固着状態となることが導出される.

\section{5. 実 験 装 置}

図 6 および図 7 は実験装置の外観を示す。振動絶 縁・抑制対象物搭載用のテーブルは $400 \times 360 \times 10$ $\mathrm{mm}$ のアルミ製で，リニアガイド ( THK 製 LSP 20100) で基礎部に支持され, 水平方向の一次元運 動を行う。また, 復原力用のばねは板ばねを使用し, 摩擦板表面には摩擦係数調整用の樹脂シートを貼付け ている。なお，レバーの支点とばねとの連接部および 摩擦板との距離は調整できるようになっている.さら に, テーブルと基礎部の間には, 一定摩擦力を調整で きる機構が設けてある.テーブル, レバーを含めたこ の装置の可動部の総質量は $m=5.357 \mathrm{~kg}$ である.レ

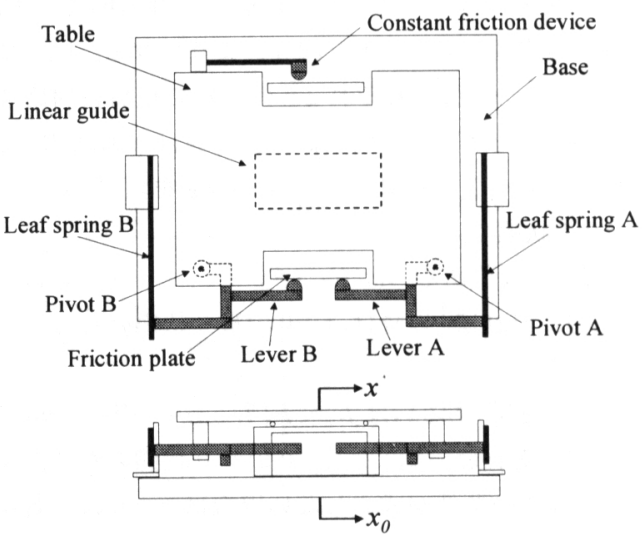

Fig. 6 Schematic of experimental apparatus

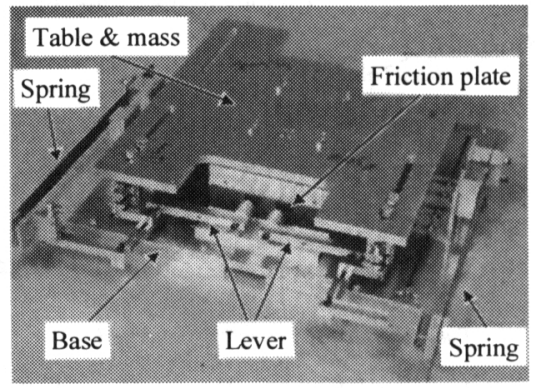

Fig. 7 Picture of experimental apparatus
バーの標準寸法は $r=130 \mathrm{~mm}, q=-52 \mathrm{~mm}, s=80$ $\mathrm{mm}$ であり, 無次元パラメータは $\varepsilon=0.615, \beta=-0.4$ となる。実験は, 基礎部を油圧加振機の加振テーブル に搭載して水平方向に正弦波変位加振し, このときの 基礎部およびテーブルの変位をレーザ変位計で計測す る.

\section{6. シミュレーションおよび実験結果}

\section{$6 \cdot 1$ 復原力特性 式 ( 8), (14)より}

$$
1+\eta_{p, m}=k_{p, m} /\left(m \omega_{0}^{2}\right)
$$

となる、これらは無次元等価ばね定数である。図 8 は $\mu \varepsilon$ を種々に設定したときの $1+\eta_{p}, 1+\eta_{m}$ と $\mu \beta$ の関 係を示す.図 8 において, $1+\eta_{p}$ は $\mu \beta$ とともに増加 し $\mu \beta=1$ で無限大となり, また, $1+\eta_{m}$ は $\mu \beta=-1$ で負の無限大となって, $|\mu \beta|$ が 1 に近づくほど, さら に, $\mu \beta$ が大きいほど $1+\eta_{p}$ と $1+\eta_{m}$ の差が大きくな る. 式(10)より, $1+\eta_{p}$ と $1+\eta_{m}$ の差が大きいほど比 例摩擦ダンパによるエネルギー消散が大きくなること が予測されるが, テーブルの復原力を保つためには原 点に戻るときの等価ばね定数は正で $1+\eta_{m}>0$ となる 必要がある。これより

$$
\mu \beta>\mu \varepsilon / 2-1
$$

という条件が得られる。

図 9 はテーブルに作用する合力 $F$ の計測例を示す. これは,テーブルを荷重変換器( $\mathrm{NEC} 三$ 栄 $9 \mathrm{E} 01$ $\mathrm{L} 45-10 \mathrm{~N})$ を介して保持し, 基礎部を一定速度 $v_{0}=$ $\dot{x}_{0}=0.1 \sim 1.0 \mathrm{~mm} / \mathrm{s}$ で三角波状に往復運動させ計測 した。図 9 において, with linear damper は比例摩擦 ダンパを作動させた場合の結果を示し, without linear damper は,レバーが摩擦板に接触しないように 固定して, 比例摩擦力 $F_{d}=0$ の場合の結果を示す. sample 1 はポリエステル製の摩擦シートを使用した 場合であり, sample 2 は摩擦係数の大きなエチレン プロピレンゴムを摩擦シートとして用い,さらに, レ バーの寸法なども比例摩擦力がより大きくなる設定と

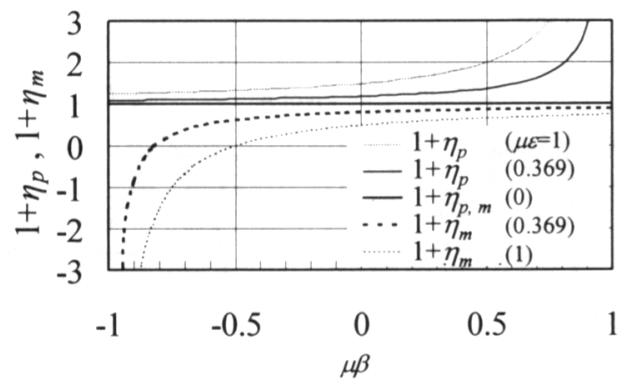

Fig. 8 Equivalent spring stiffness 
なっている．比例摩擦ダンパを作動させた場合， sampl 1では合力の履歴特性は相対速度によってほと んど変化しないが, sample 2 では相対速度の大きさ によって変化する．命力と相対変位の関係を直線で近 似して求めた傾き拀よび切片を式（７）に当てはめて， 一定摩擦力 $F_{c 0}$, ばね定数 $k$ および比例摩擦ダンパの 摩擦係数 $\mu$ を推定すると表 10 ○うになる，以降の 実験抢よびシミュレーションでは, 摩擦係数の速度依 存性や摩擦シート0耐摩耗性などを考虑して, sam ple 1 の設定を用いた.

\section{2 制振性能(残留変位) 悯 10 は初期相対変位} $z(0)=10 \mathrm{~mm}$, 初期相対速度 $\dot{z}(0)=0 \mathrm{~mm} / \mathrm{s}$ で自由振 動させた場合の実験結果を示し，比例摩擦ダンパが作 動しない場合 (without linear damper)と作動した場

Table 1 System parameters

\begin{tabular}{|c|c|c|}
\hline & (a) Sample 1 & (b) Sample 2 \\
\hline Friction sheet & Poly-ester & Ethylene Propylene \\
\hline$\varepsilon$ & 0.615 & 0.679 \\
\hline$\beta$ & -0.40 & -0.77 \\
\hline$k[\mathrm{~N} / \mathrm{m}]$ & $0.75 \times 10^{3}$ & $1.16 \times 10^{3}$ \\
\hline$\mu$ & 0.60 & $0.75 \sim 0.95$ \\
\hline$F_{\curvearrowright 0}[\mathrm{~N}]$ & 0.60 & 0.74 \\
\hline$m[\mathrm{~kg}]$ & \multicolumn{2}{|c|}{5.357} \\
\hline
\end{tabular}

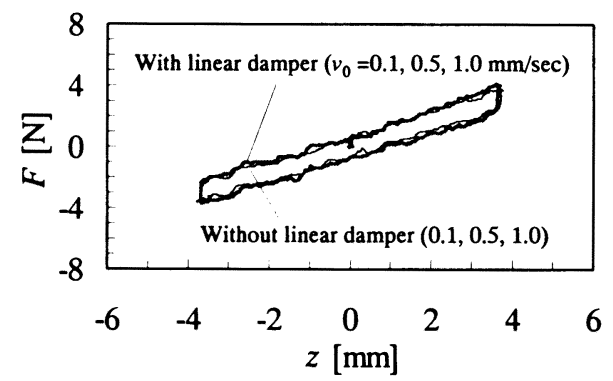

(a) Sample 1 (Friction sheet: Poly ester, $\varepsilon=0.615, \quad \beta=$ $-0.4)$

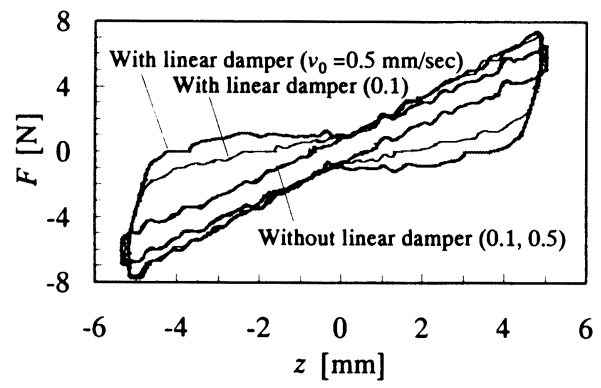

(b) Sample 2 (Friction sheet: Ethylene Propylene, $\varepsilon=0.679$, $\beta=-0.77)$

Fig. 9 Resultant force acting on the table (experiment) 合(with linear damper), さらに, 比例摩擦ダンパが 作動しない状態で一定摩擦力を大きくした場合の相対 変位時刻歷応答の計測結果の比較である. $d_{0}=F_{c 0} / k$ $=0.8 \mathrm{~mm}$ の場合, without linear damper と with linear damperでは残留変位はほぼ同じであるが, with linear damperの場合のほうが振動の減衰はよ り速やかになっている. without linear damper で一 定摩擦力を大きくする $\left(d_{0}=2.6 \mathrm{~mm}\right)$ と, 振動の減衰 は早まるが，それに伴って残留変位が増大する。この ように, 本研究で提案する比例摩擦ダンパは, 自由振 動を速やかに減衰させつつ, 残留変位の抑制効果も維 持できる。

残留変位について詳細に検討するため, 式(21)にお いて $X_{0}=0$ とすると

$$
|z|<d_{0} /\left(1+\eta_{m}\right)
$$

を得る.これは, 基礎部を固定しテーブルを自由振動 させた場合の残留変位の生じる範囲を表し, この範囲 内で相対速度が零になったときに, テーブルはその位 置で停止する. なお, 一定摩擦力のみの場合には, 最 大残留変位は $d_{0}$ であり, また, 一定摩擦力がない場合 は残留変位が生じない. 図 11 は $d_{0}>0$ の場合の最大 残留変位 $|z|_{\max }=d_{0} /\left(1+\eta_{m}\right)$ と $\mu \varepsilon, \mu \beta$ の関係を示す. $\mu \beta$ を小さくした場合, 残留変位が急激に増加する範 囲がある。これは, 図 8 に示したように, 等価ばね定 数 $1+\eta_{m}$ が零に近づき, 復原力が小さくなるためであ

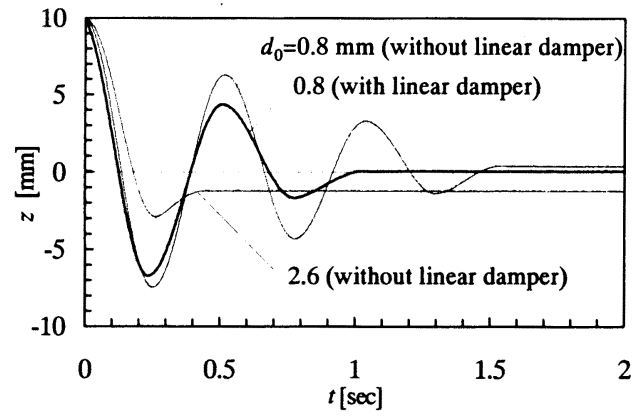

Fig. 10 Free vibration (experimental result)

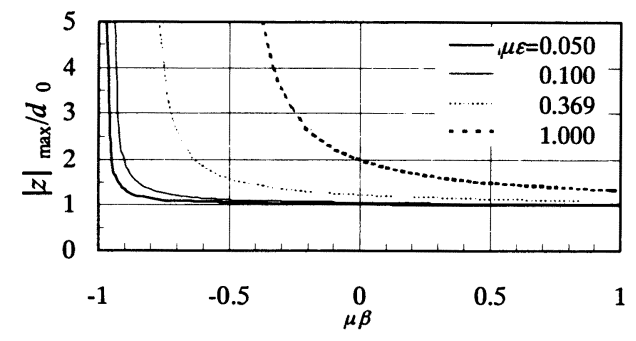

Fig. 11 Maximum residual displacement 
る.

$6 \cdot 3$ 振動絶縁性能振動絶縁性能を評価するた めに基礎部を正弦波変位加振した場合の変位伝達率

$$
T=\sqrt{\int x^{2} d t / \int x_{0}^{2} d t}
$$

を調べる。

図 12 は基礎部の加振変位振幅を $X_{0}=0.5,1.0,1.5$ $\mathrm{mm}$ の三とおり変化させた場合の変位伝達率と加振 振動数 $f$ の関係のシミュレーションおよび実験結果 である. 比例摩擦ダンパが作動していない状態 (without linear damper)では, 図 12 ( a )のように加振振幅 が比較的小さい場合，リニアガイドなどによる一定摩 擦力による減衰のみで固有振動数 $f_{0}=\omega_{0} / 2 \pi=1.88$ $\mathrm{Hz}$ 付近の伝達率が抑制されているが, 図 $12(\mathrm{~b})$ およ び ( c )のように加振振幅が増大すると, 固有振動数付 近の伝達率が急激に増大する. 一方, 比例摩擦ダンパ を作動させた場合 (with linear damper)では, 高振動 数域における伝達率を without linear damper の場合 と同等に抑えつつ, 固有振動数付近の伝達率のピーク を抑制している。

ところで, 固有振動数 $f_{0}$ で加振された場合, 基礎部 の強制変位によってなされる仕事 $U_{I}$ は

$$
U_{I}=\pi P z_{\max }, \quad P=k X_{0}
$$
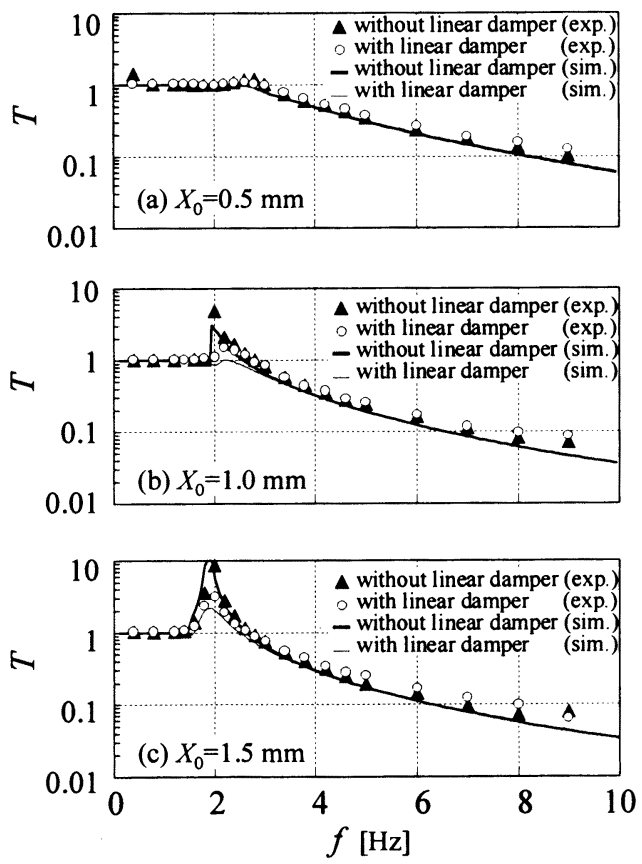

Fig. 12 Displacement transmissibility (simulation and experiment ; $f_{0}=1.88 \mathrm{~Hz}, \quad d_{0}=0.8 \mathrm{~mm}, \quad \mu \varepsilon=$ $0.369, \mu \beta=-0.24)$
となり, 相対変位の振幅 $z_{\max }$ に比例する. 式( 9 )の 説明で述べたように, 一定摩擦力 $F_{c 0}$ のみの場合に消 散されるエネルギー $U_{D C}=4 F_{C 0} z_{\max }$ も $z_{\max }$ に比例す るため, $\pi P>4 F_{c 0}$ の場合には, 図 $13(\mathrm{a})$ に示すよう に常に $U_{I}$ が $U_{D C}$ より大きくなって, 共振時の応答振 幅が無限大に増大することが知られている(8). 一方, 粘性減衰係数 $c$ のダッシュポットを取付けた場合, 消 散されるエネルギー $U_{D V}=2 \pi^{2} c f z_{\max }^{2}$ は振幅の二乗に 比例するため, 図 $13(\mathrm{~b})$ に示すように $U_{1}$ と釣合う有 限の共振振幅となる：式(9)0)説明で述べたように， 比例摩擦力による消散エネルギー $U_{D P}=\left(k_{p}-k_{m}\right) z_{\max }^{2}$ も振幅の二乗に比例するため, 比例摩摖ダンパを作動 させた場合の伝達率は粘性減衰と同様に共振振幅が有 限になることが確認される，なお，粘性隇衰による消 散エネルギー $U_{D V}$ は $f$ に比例して変化するため, 振 動数が小さい範囲では消散エネルギーが小さくなるの に対し, 比例摩擦力による消散エネルギー $U_{D P}$ は振 動数に依存しないことが特徴的である.

図 14 は, 式(20)，（21）で示したように，常に滑り状 態，および固着状態となる相対変位の範囲と加振振動 数の関係を $d_{0}>0$ の場合について示す。四 14 におけ る上側の曲線より上の領域では常に滑り状態となり, 下側の曲線より下の領域では常に固着状態となる。な お,これらの間の領域では，状況により固着および滑 りが生じる。これらの図より，常に固着状態となるの は加振振動数および加振振幅の小さい領域であるが,

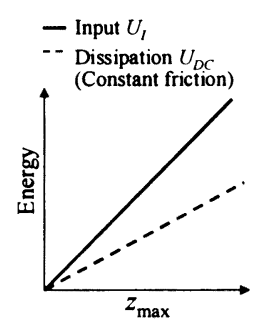

(a)

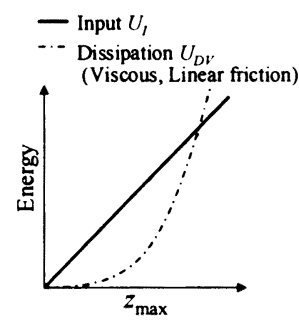

(b)
Fig. 13 Energy relations at resonances

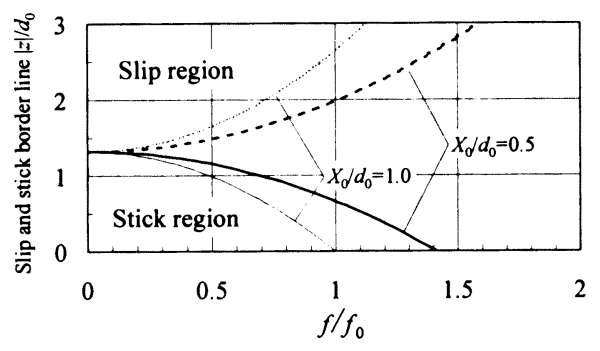

Fig. 14 Slip and stick region $(\mu \varepsilon=0.369, \mu \beta=-0.24)$ 


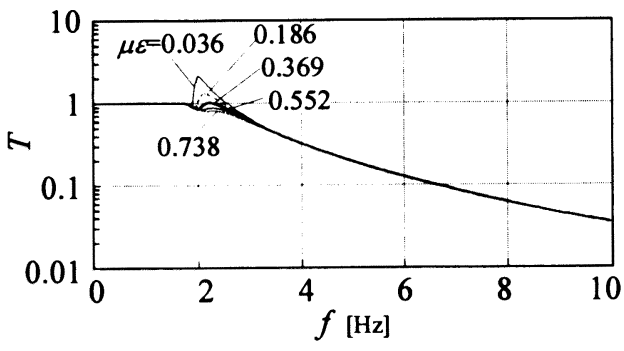

Fig. 15 Displacement transmissibility (simulation; $f_{0}$ $\left.=1.88 \mathrm{~Hz}, d_{0}=0.8 \mathrm{~mm}, \mu \beta=-0.24, X_{0}=1 \mathrm{~mm}\right)$

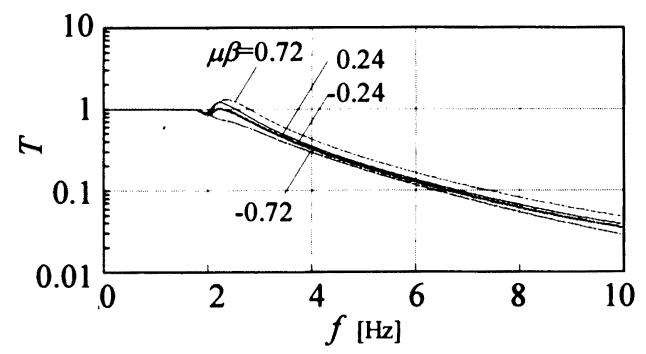

Fig. 16 Displacement transmissibility (simulation; $f_{0}$ $=1.88 \mathrm{~Hz}, d_{0}=0.8 \mathrm{~mm}, \mu \varepsilon=0.369, X_{0}=1 \mathrm{~mm}$ )

加振振幅が小さいほど常に活着状態となる振動数の範 囲が広がることがわかる。戍 12 においても，加振振 動数が小さい範囲で湖着が生じ, 変位伝達率は 1 であ る. 特に, 加振振幅 $0.5 \mathrm{~mm}$ の場合には, $2.5 \mathrm{~Hz}$ 付近 まで変位伝達率が1となって, 共振ピークは見られな くなる.

図 15 および四 16 は, $\mu \varepsilon, \mu \beta$ を種々に設定したと きの変位伝達率のシミュレーション結果例である. 図 15,16 より, 式(23)の制約のもとで, $\mu \varepsilon$ が大きく, $\mu \beta$ が -1 に近いほど共振ピークが抑制され, 伝達率 全体も低くなることがわかる.そこで， $\mu \beta=-0.72$, $\mu \varepsilon=0.552$ とした場合について振幅 $X_{0}$ の影響を調べ ると, 図 17 のようになる。図 14 からも予測されるよ うに， $X_{0}$ が小さくなると固着状態が振動数の高い範 井まで広がり振動絶緑性能は悪化する。また理想的な 場合として, 一定摩擦力が $0\left(d_{0}=0\right)$ 0)場合には, 図 18 に示すように, 振幅によらず高振動数域における伝達 率を抑制しつつ共振ピークを低く抑えている。これ は, 能動型振動絶縁方式のスカイフックダンパ(13) と 同様な振動絶縁性能が期待されることを示している.

\section{7. 結 言}

摩擦ダンパを用いた振動絶縁装置において, 摩擦力 が相対変位に比例して変化する機構を提案し, その特

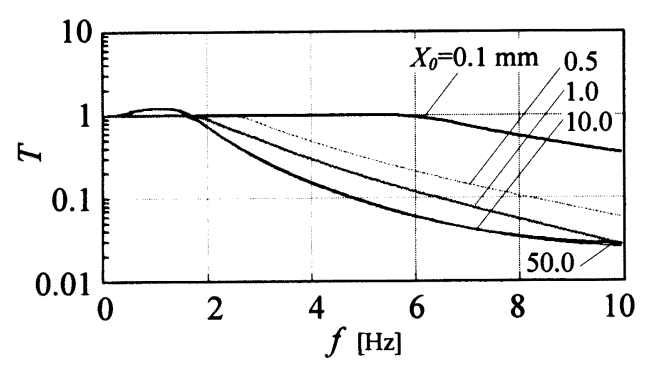

Fig. 17 Displacement transmissibility (simulation; $f_{0}$ $=1.88 \mathrm{~Hz}, d_{0}=0.8 \mathrm{~mm}, \mu \varepsilon=0.552, \mu \beta=-0.72$ )

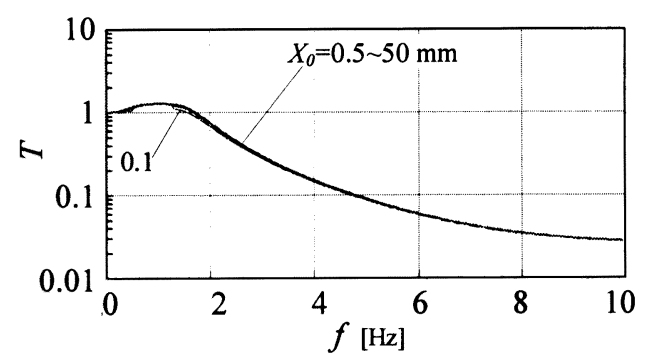

Fig. 18 Displacement transmissibility (simulation; $f_{0}$ $=1.88 \mathrm{~Hz}, d_{0}=0 \mathrm{~mm}, \mu \varepsilon=0.552, \mu \beta=-0.72$ )

性を調べた。主な結果は以下のとおりである.

（1）比例摩擦力によって消散されるエネルギーは 粘性減衰と同様に振幅の二乗に比例し, かつ加振振動 数に依存しない.

（2）一定摩擦力のみの場合には, 共振ピークが無 限大になることがあるが, 比例摩擦力の場合には, 粘 性減衰と同様に無限大になることはない.

（3）高振動数域における伝達率を増加させること なく，共振ピークを振制できることを確認した。

（4）比例摩擦力のみでは残留変位を生じない.

（5）常に固着あるいは滑り状態が生じる範囲を示 した.

終わりに，実験装置の製作および実験を行うに当た り, 防衛大学校平成 14 年度卒研生の中原利通君の助 力を得た。ここに謝意を表す。

\section{文献}

（1）岩田義明・大塩真・鈴木登・内田公夫・唐沢好一, 精密 除振装置のアクティブコントロール，機論， 57-534，C (1991), 521-526.

（2）岡野恭久・松岡太一・大亦絢一郎, 二リンク・三関節を 持つアーム形摩摖ダンパの研究, 機論, 69-678, C (2003), $335-342$.

（3）武田寿一，構造物の免震，防振，制振，(1988)，48-50, 技報 堂出版.

（4）岡村茂樹・藤田聡, 摩擦振り子型免震装置群の地震時挙 
動に関する研究, 機論, 67-660, C (2001), 2456-2463.

（5）藤田隆史・服部忍・石田二郎，予引張りばねを利用した 免震床の研究, 機論, 49-441, C (1983), 727-736.

（6）笹本好章・曽田五月也，残留変形を抑制するパッシブ制 振システムに関する研究, 第 2 回ダンピングシンポジウ ム講演会論文集, (2002-1), 251-254.

( 7 ) Schlesinger, A., Vibration Isolation in The Presence of Coulomb Friction, J. Sound Vib., 63-2 (1979), 213-224.

(8) Den Hartog, J. P., Forced Vibrations with Combined Coulomb and Viscous Friction, Trans. ASME, J. Appl. Mech., 53-9 (1931), 107-115.

(9) Beucke, K.E. and Kelly, J. M., EQUIVALENT LINEARIZATIONS FOR PRACTICAL HYSTERETIC SYSTEMS, Int. J. Non-Linear Mech., 23-4
(1985), 211-238.

(10) Makris, N. and Constantinou, M. C., Analysis of Motion Resisted by Friction. I . Constant Coulomb and Linear/Coulomb Friction, Mech. Struct. Machines, 19-4 (1991), 477-500.

(11) Makris, N. and Constantinou, M. C., Analysis of Motion Resisted by Friction. II. Velocity-Dependent Friction, Mech. Struct. Machines, 19-4 (1991), 501-526.

(12) Tadjbakhsh, I. and Lin, B. C., DISPLACEMENT. PROPORTIONAL FRICTION (DPF) IN BASE ISO. LATION, Earthq. Eug. Struct. Dyn., 15 (1987), 799-813.

(13) Griffin, S., Gussy, J., Lane, S. A., Henderson, B. K. and Sciulli, D., Virtual Skyhook Vibration Isolation System, Trans. ASME, J. Vib. Acoust., 124 (2002), 63-67. 